\title{
Characterization of glutamine uptake in mouse two-cell embryos and blastocysts
}

\author{
A. McD. Lewis and P. L. Kaye* \\ Department of Physiology and Pharmacology, The University of Queensland, Brisbane, \\ Queensland 4072, Australia
}

\begin{abstract}
Summary. Mouse two-cell embryos and blastocysts take up $\left[{ }^{3} \mathrm{H}\right]$ glutamine in vitro at a constant rate for at least $15 \mathrm{~min}$, depending on the concentration of glutamine and developmental stage of the embryo. Uptake by two-cell embryos can be resolved into two saturable components. The major contributing system is $\mathrm{Na}^{+}$independent, inhibited by alanine, methionine, 2-amino-2-norbornanecarboxylic acid (BCH) or leucine and has a $K_{\mathrm{m}}$ of $3856 \pm 672 \mu \mathrm{moll}^{-1}$ and $V_{\max }$ of $436 \pm 58 \mathrm{fmol}$ per embryo per $10 \mathrm{~min}$. These features are characteristics of the ubiquitous system $\mathbf{L}$ transporter. The second component is $\mathrm{Na}^{+}$dependent with $K_{\mathrm{m}}$ of $1064 \pm 914 \mu \mathrm{mol} 1^{-1}$ and $V_{\max }$ $107 \pm 47 \mathrm{fmol}$ per embryo per $10 \mathrm{~min}$. Similar $V_{\max }$ and inhibition of this component by glycine suggest a low reactivity with the $g l y$-system. Blastocyst uptake of glutamine is mainly by a $\mathrm{Na}^{+}$-dependent saturable mechanism with $K_{\mathrm{m}}$ of $524 \pm 75 \mu \mathrm{mol}^{-1}$ and $V_{\max }$ of $1264 \pm 101 \mathrm{fmol}$ per embryo per $10 \mathrm{~min}$ which is inhibited by alanine, isoleucine, leucine and $\mathrm{BCH}$, features characteristic of the system $\mathrm{B}^{0,+}$. The increase in uptake capacity as a consequence of the appearance of the system $\mathrm{B}^{0,+}$ may be related to increased metabolic requirements for glutamine, in the rapidly expanding blastocyst.
\end{abstract}

Keywords: glutamine transport; blastocyst; embryo; system L; system $\mathbf{B}^{0 .+}$; mouse

\section{Introduction}

Glutamine is an important component of many mammalian cell culture media. As well as aiding the maturation and development of embryos from many species (hamster: Gwatkin \& Haidri, 1973; Carney \& Bavister, 1987; rabbit: Bae \& Foote, 1975; pig: Petters et al., 1990; mouse: Chatot et al., 1990 ), it has been identified as a major alternative energy source to glucose for bovine blastocysts (Rieger \& Guay, 1988) and human diploid fibroblasts (Zielke et al., 1984).

The concentration of glutamine in mouse oviductal fluid is high (Gardner \& Leese, 1990). The uptake of glutamine by preimplantation embryos in vitro has been measured with ultramicrofluorometry (Gardner et al., 1989) and radiolabelled glutamine (Chatot et al., 1990), but the specific transporting system into the embryo has not been identified.

Study of amino acid uptake has led to the identification of several specific transport mechanisms. In preimplantation mouse embryos, these include the $\mathrm{Na}^{+}$-independent system $\mathrm{L}$ (Christensen, 1979), present in all preimplantation stages, and the $\mathrm{Na}^{+}$-dependent system $g l y$ (Hobbs \& Kaye, 1985, 1986), most apparent in two-cell embryos, and $\mathrm{B}^{0,+}$ (Van Winkle \& Campione, 1987; Van Winkle, 1988), which appears at about compaction and becomes increasingly dominant in activity at the blastocyst stage.

This study aimed to determine the specific mode of glutamine uptake by mouse embryos at the two-cell and blastocyst stages. 


\section{Materials and Methods}

\section{Superovulation and embryo collection}

Randomly bred Quackenbush mice (10 weeks) were superovulated with 5 iu pregnant mares' serum gonadotrophin (PMSG) (Folligon: Intervet (Aust Pty Ltd, Artarmon, NSW, Australia), followed $44-50 \mathrm{~h}$ later by 5 iu human chorionic gonadotrophin (hCG) (Chorulon: Intervet (Aust)). Injections were given between 09:00 and 12:00 h. Immediately after hCG injection, females were placed with males and left until 09:00 h on the following day, when they were checked for vaginal plugs. Two-cell and blastocyst embryos were collected from the oviduct ( $48 \mathrm{~h}$ after hCG) or uterus ( $96 \mathrm{~h}$ after hCG), respectively, into M2 medium (Fulton \& Whittingham, 1978).

Radioactive media were prepared by the addition of $\mathrm{M} 2$ containing glutamine at the appropriate concentrations, to freeze-dried $\left[{ }^{3} \mathrm{H}\right]$ glutamine $\left(1 \mathrm{Ci}^{-1}, 46 \mathrm{Ci} \mathrm{mmol}^{-1},\left[\mathrm{G}-{ }^{3} \mathrm{H}\right]\right.$ glutamine (Amersham, North Ryde, NSW, Australia)) or $\left[{ }^{3} \mathrm{H}\right]$ glycine $\left(1 \mathrm{Ci}^{-1}, 18 \cdot 5 \mathrm{Ci} \mathrm{mmol}^{-1},\left[2{ }^{3} \mathrm{H}\right]\right.$ glycine (Amersham)).

\section{$\mathrm{Na}^{+}$-free medium $\mathrm{M} 2$}

Medium M2 was prepared without $\mathrm{Na}^{+}$by replacing $\mathrm{NaCl}$ and $\mathrm{NaHCO}_{3}$ on an equimolar basis with choline chloride and $\mathrm{KHCO}_{3}$, respectively. The Hepes was brought to $\mathrm{pH} 7.4$ with $\mathrm{KOH}$. Embryos were incubated for 30 min in this medium.

\section{Glutamine uptake}

Glutamine uptake was measured by incubating embryos on a heating block at $37^{\circ} \mathrm{C}$, in a $20-50 \mu$ droplet of radioactive medium under $3 \mathrm{ml}$ of light paraffin oil (Caltex, Australia Pty Ltd, Brisbane) in a plastic Petri dish. After a specific time, the embryos were removed from the droplet and washed four times in ice-cold M2 without glutamine. Afterwards they were placed into plastic minicounting vials and $0.1 \mathrm{ml} \mathrm{H}_{2} \mathrm{O}$ and $1.0 \mathrm{ml}$ Optiphase Hi-safe 3 counting cocktail (LKB, Wallac, Bromma, Sweden) was added before analysis in a Packard 1900 CA liquid scintillation system. $\mathrm{Na}^{+}$-dependent uptake was calculated by subtracting the mean rate of uptake in the absence of $\mathrm{Na}^{+}$from the mean rate of uptake in the presence of $\mathrm{Na}^{+}$.

\section{Descending paper chromatography}

Blastocysts were incubated for $10 \mathrm{~min}$ in medium containing $19 \mu \mathrm{mol}\left[{ }^{3} \mathrm{H}\right]$ glutamine $1^{-1}$, washed rapidly in icecold M2 then placed into $10 \mu \mathrm{l} \mathrm{M} 2$ to which was added $10 \mu \mathrm{l} 20 \% \mathrm{CCl}_{3} \mathrm{COOH}$. After centrifuging for $5 \mathrm{~min}$ at $5000 \mathrm{~g}$, the supernatant was spotted on to $3 \mathrm{M}$ filter paper and separated using $12: 3: 5, \mathrm{CH}_{3}(\mathrm{CH} 2)_{2} \mathrm{CH}_{2} \mathrm{OH}$ : $\mathrm{CH}_{3} \mathrm{COOH}: \mathrm{H}_{2} \mathrm{O}$ as the solvent. Nonradioactive marker glutamine was located by ninhydrin. The filter paper was cut into $1 \cdot 5-\mathrm{cm}$ squares and radioactivity was determined.

\section{Glutamine efflux}

Embryos were incubated at $37^{\circ} \mathrm{C}$ for $10 \mathrm{~min}$ in $\left[{ }^{3} \mathrm{H}\right]$ glutamine, rapidly washed and replaced into a droplet of medium without glutamine. Samples of embryos were taken at various times and prepared for liquid scintillation analysis as described previously.

\section{Competition}

Embryos were incubated in media containing $19 \mu \mathrm{mol}\left[{ }^{3} \mathrm{H}\right]$ glutamine $\mathrm{l}^{-1}$ and one of the following at $1 \mathrm{mmol}^{-1}$ : leucine, 2-amino-2-norbornanecarboxylic acid $(\mathrm{BCH})$, alanine, lysine, isoleucine, methylaminoisobutyric acid (MeAIB), tryptophan, D-glutamine or glycine. After $10 \mathrm{~min}$, the embryos were removed, washed and analysed.

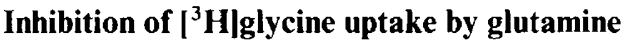

Embryos were incubated in medium containing $18.5 \mu$ mol $\left[{ }^{3} \mathrm{H}\right]$ glycine $1^{-1}$ and $0 \cdot 2,1,5$ or $25 \mathrm{mmol}$ unlabelled glutamine $\mathrm{l}^{-1}$. After $10 \mathrm{~min}$, the embryos were removed, washed and analysed.

\section{Standardization}

All measurements of uptake were internally standardized as follows: at the end of an incubation, radioactivity was measured in samples of the medium and the mean was used to calculate the specific radioactivity of the droplet, using 
the known glutamine concentration and allowing for the contribution of $\left[{ }^{3} \mathrm{H}\right]$ glutamine. Background samples consisted of equivalent volumes to that transferred with the embryos being collected from the final wash medium. The measurements obtained rarely differed from standard background measurements. The counting efficiency was $40 \%$ with a standard background of $10-12$ c.p.m.

Values presented are means \pm SEM of three experiments containing 6-14 observations unless otherwise indicated. Kinetic parameters for saturable glutamine uptake were determined by nonlinear regression using the equation $v=$ $K_{0}[\mathrm{Gln}]+\left(V_{\max }[\mathrm{Gln}] / K_{\mathrm{m}}+[\mathrm{Gln}]\right)$ where $v$ is the initial rate of uptake, $K_{0}$ is the rate constant for the nonsaturable transport and $K_{\mathrm{m}}$ and $V_{\max }$ are the kinetic parameters describing the saturable transport component (Duggleby, 1984; Hobbs \& Kaye, 1990). Lines of best-fit were calculated from the linear regression for uptake experiments.

\section{Results}

Paper chromatography revealed that at least $90 \%$ of the radioactivity in blastocysts after incubation for $10 \mathrm{~min}$ partitioned with glutamine.

There was no significant loss of pre-accumulated $\left[{ }^{3} \mathrm{H}\right]$ glutamine into amino-acid-free medium on ice by two-cell embryos after preloading in medium containing $100 \mu \mathrm{mol}$ or $1 \mathrm{mmol}$ glutamine $1^{-1}$. Loss by blastocysts over $15 \mathrm{~min}$ was not significant when preloading occurred in $100 \mu \mathrm{mol}$ $\left[{ }^{3} \mathrm{H}\right]$ glutamine $\mathrm{l}^{-1}$, but, when preloading occurred in $1 \mathrm{mmol}$ glutamine $\mathrm{l}^{-1}$, about $30 \%$ of accumulated glutamine was lost after $15 \mathrm{~min}$ (Fig. 1). Thus, losses during the washing procedure of about $5 \mathrm{~min}$ were insignificant.

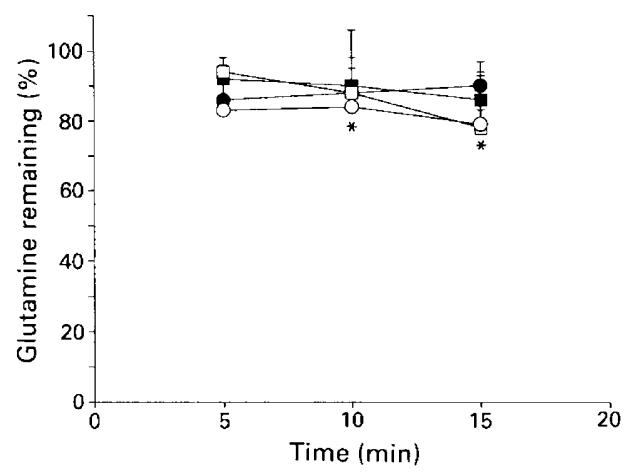

Fig. 1. Efflux of $\left[{ }^{3} \mathrm{H}\right]$ glutamine on ice from two-cell mouse embryos preloaded at $37^{\circ} \mathrm{C}$ with $100 \mu \mathrm{mol}(0)$ or $1 \mathrm{mmol}$ glutamine $1^{-1}(\boldsymbol{U})$ and blastocysts at $100 \mu \mathrm{mol}(\bigcirc)$ and $1 \mathrm{mmol}(\square)$ glutamine $1^{-1}$. Results from two experiments, mean \pm SEM each with four to seven embryos per time point; *significantly less than value at zero time $(P<0.05)$ for blastocysts preloaded with $1 \mathrm{mmol}$ glutamine $1^{-1}$.

\section{Uptake}

Two-cell embryos took up $\left[{ }^{3} \mathrm{H}\right]$ glutamine at a constant rate of $1.8 \mathrm{fmol}$ per embryo $\mathrm{min}^{-1}(r=$ $0.92, n=48, P<0.001$ ) for at least $30 \mathrm{~min}$ at $37^{\circ} \mathrm{C}$ in $100 \mu \mathrm{mol}$ glutamine $1^{-1}$ (Fig. 2a) and $5.6 \mathrm{fmol}$ per embryo $\min ^{-1}(r=0.87, n=56, P<0.001)$ for at least $15 \mathrm{~min}$ in 1 mmol glutamine $1^{-1}$ (data not shown). Afterwards the uptake rate appeared to plateau.

Blastocysts maintained a constant uptake rate of $33 \mathrm{fmol}$ per embryo $\mathrm{min}^{-1}$ over $60 \mathrm{~min}$ ( $r=0.93, n=52, P<0.001)$ in $100 \mu \mathrm{mol}$ glutamine $1^{-1}$ (Fig. 2b).

\section{$\mathrm{Na}^{+}$-free conditions}

Uptake of glutamine by two-cell embryos (Fig. 2a) and blastocysts (Fig. 2b), incubated in $\mathrm{Na}^{+}$free M2 containing $100 \mu \mathrm{mol}$ glutamine $1^{-1}$, was constant over at least $60 \mathrm{~min}$. In the absence 


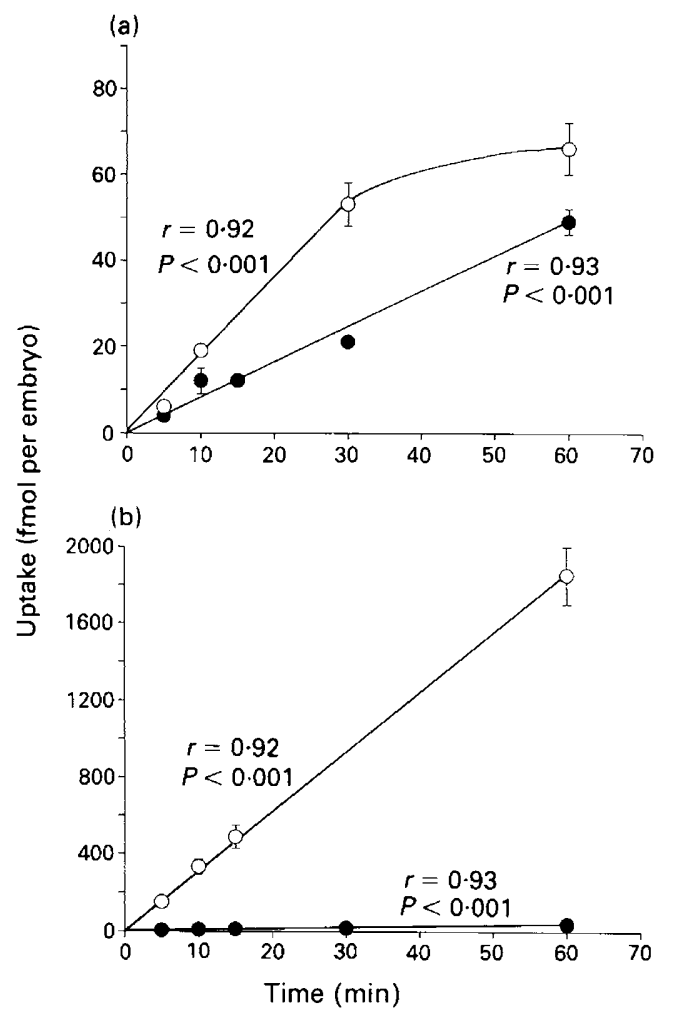

Fig. 2. Glutamine $\left(100 \mu \mathrm{mol}^{-1}\right)$ uptake by two-cell mouse embryos (a) or blastocysts (b) incubated at $37^{\circ} \mathrm{C}$. Each point represents $4-6$ embryos, mean \pm SEM from three experiments: $\mathrm{Na}^{+}$present $(\mathrm{O})$ or absent $(\bullet)$ from medium $\mathrm{M} 2$.

of $\mathrm{Na}^{+}$, the uptake of glutamine by two-cell embryos was reduced by about $30 \%$ and in blastocysts by about $98 \%$.

\section{Saturation kinetics}

Total uptake of glutamine by two-cell embryos did not reach a plateau even at $12 \mathrm{mmol} \mathrm{l}^{-1}$, indicating a nonsaturable component. The uptake could be divided into a saturable $\mathrm{Na}^{+}$dependent component and a $\mathrm{Na}^{+}$-independent component that appeared not to be saturable (Fig. 3a). The kinetic parameters for the $\mathrm{Na}^{+}$-dependent component were $K_{\mathrm{m}} 1064 \pm 914 \mu \mathrm{mol}^{-1}$ and $V_{\max } 107 \pm 47 \mathrm{fmol}$ per embryo per $10 \mathrm{~min}$, fitted using nonlinear regression analysis and allowing for a nonsaturable component.

The $\mathrm{Na}^{+}$-independent component had the following values: $K_{\mathrm{m}} 3856 \pm 672 \mu \mathrm{mol} \mathrm{l}^{-1}$ and $V_{\max }$ $436 \pm 58 \mathrm{fmol}$ per embryo per $10 \mathrm{~min}$ by nonlinear regression, when the nonsaturable rate constant was set at $9 \mathrm{pl}$ per embryo per $10 \mathrm{~min}$ as reported by Hobbs \& Kaye (1990). Graphical analysis using Eadie-Hofstee plots (Van Winkle et al., 1990) allowing for a nonsaturable component with rate constant 9 pl per embryo per $10 \mathrm{~min}$ (Hobbs \& Kaye, 1990) showed only one saturable component of $\mathrm{Na}^{+}$-independent uptake (Fig. 3) with $K_{\mathrm{m}} 2767 \pm 525 \mu \mathrm{mol}{ }^{-1}$ and $V_{\max } 369 \pm 50 \mathrm{fmol}$ per embryo per $10 \mathrm{~min} ; n=8, r=0.900$, not significantly different from values estimated by nonlinear regression.

Total glutamine uptake by blastocysts appeared to be saturable up to $2 \mathrm{mmol}^{-1}$ at $37^{\circ} \mathrm{C}$ (Fig. 4a). Nonlinear curve fitting showed $K_{\mathrm{m}} 524 \pm 75 \mu \mathrm{mol} \mathrm{1^{-1 }}$ and $V_{\max } 1264 \pm 101 \mathrm{fmol}$ per embryo per $10 \mathrm{~min}$, when the rate constant for the nonsaturable component was set at $40 \mathrm{pl}$ per embryo per $10 \mathrm{~min}$ (Hobbs \& Kaye, 1990). Graphical analysis using Eadie-Hofstee plots with a set 


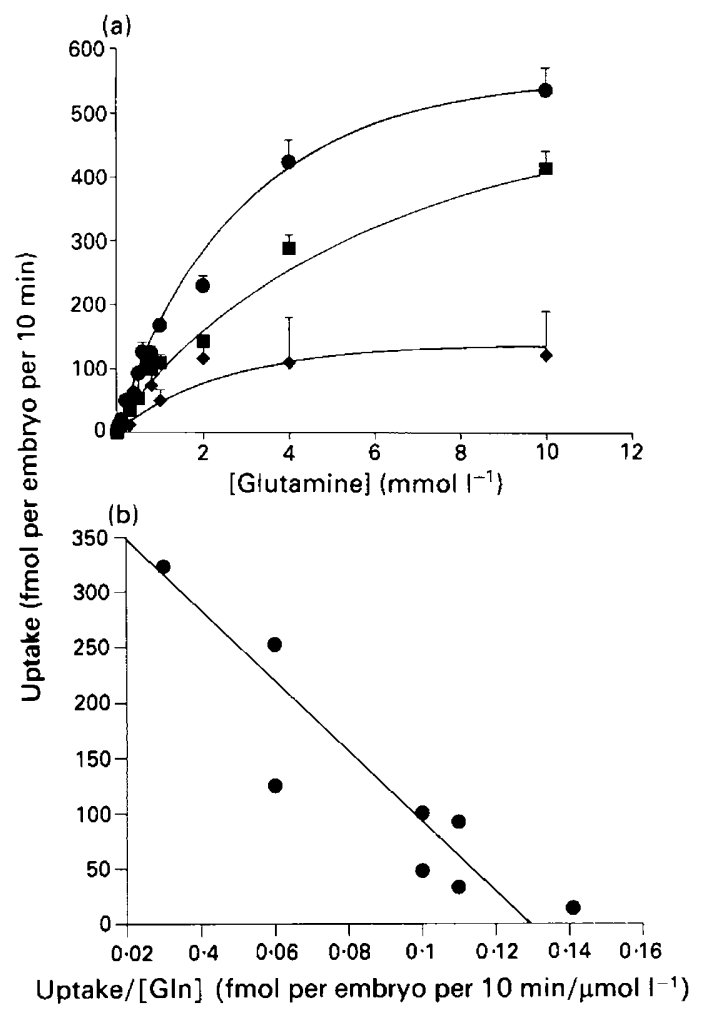

Fig. 3. Saturation curves of glutamine uptake by two-cell mouse embryos at $37^{\circ} \mathrm{C}$. Each point represents 4-8 embryos, mean \pm SEM from five experiments, total glutamine uptake $(\bullet)$, $\mathrm{Na}^{+}$-independent uptake $(\boldsymbol{\square})$ and $\mathrm{Na}^{+}$-dependent curves $(\bullet)$. (a) The lines were fitted to the equation $v=K_{0}[\mathrm{Gln}]+V_{\max }[\mathrm{Gln}] / K_{\mathrm{m}}+[\mathrm{Gln}]$ with $K_{0} 9 \mathrm{pl}$ per embryo per $10 \mathrm{~min}, K_{\mathrm{m}}$ $3856 \mu \mathrm{mol}^{-1}$ and $V_{\max } 436 \mathrm{fmol}$ per embryo per $10 \mathrm{~min}$ in the absence of $\mathrm{Na}^{+}, K_{0} 0, K_{\mathrm{m}}$ $1064 \mu \mathrm{mol}^{-1}$ and $V_{\max } 107 \mathrm{fmol}$ per embryo per $10 \mathrm{~min}$ for $\mathrm{Na}^{+}$dependent. (b) The data for $\mathrm{Na}^{+}$-independent uptake were transformed into an Eadie-Hofstee plot with same allowance for diffusion and fitted by linear regression, $n=8, r=0.90, P<0.05$.

nonsaturable rate constant of $40 \mathrm{pl}$ per embryo per $10 \mathrm{~min}$ showed only one saturable component (Fig. 4b) with $K_{\mathrm{m}} 252 \pm 110 \mu \mathrm{mol}^{-1}$ and $V_{\max } 1049 \pm 212 \mathrm{fmol}$ per embryo per $10 \mathrm{~min}$, which are comparable to the values obtained by nonlinear regression.

\section{Competition with other amino acids}

When incubated with $1 \mathrm{mmol}$ isoleucine, tryptophan or leucine $1^{-1}$, two-cell embryos showed a significant reduction in glutamine uptake (Fig. 5). There was no significant inhibition by alanine, glycine, MeAIB, D-glutamine or BCH in normal M2, but, when embryos were incubated in $\mathrm{Na}^{+}-$ free $\mathrm{M} 2$ (Fig. 5b) with $1 \mathrm{mmol}$ alanine, leucine, methionine or $\mathrm{BCH} 1^{-1}$, there was a significant inhibition, the last three being about five times more effective than alanine.

Glutamine inhibited the uptake of $\left[{ }^{3} \mathrm{H}\right]$ glycine $\left(23 \mu \mathrm{mol} \mathrm{l}^{-1}\right)$ when two-cell embryos were incubated at $37^{\circ} \mathrm{C}$ for $10 \mathrm{~min}$ in the presence of $\mathrm{Na}^{+}$(Fig. 6). There was no inhibition with $0.2 \mathrm{mmol}$ glutamine $1^{-1}$, but at 1,5 and $25 \mathrm{mmol}^{-1}$ glycine uptake was inhibited by at least $30 \%$.

At the blastocyst stage (Fig. 7), glutamine uptake was significantly inhibited by alanine, isoleucine, tryptophan, leucine, lysine, glycine (50-70\%), and by $\mathrm{BCH}$ (about $30 \%$ ). There was no significant inhibition by MeAIB. 


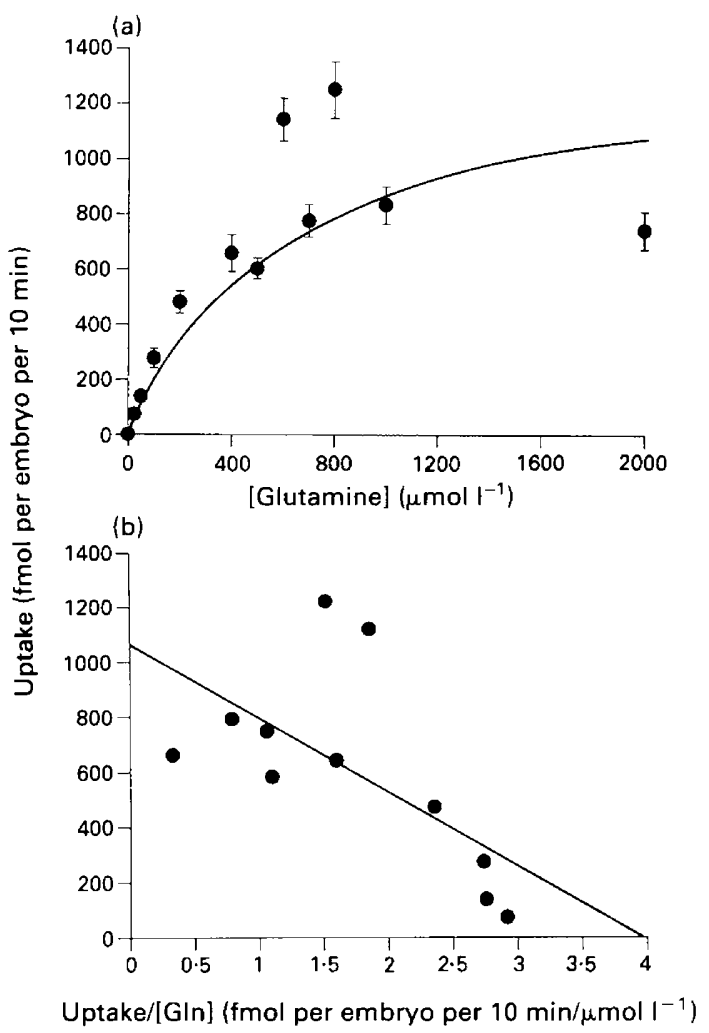

Fig. 4. $\mathrm{Na}^{+}$-dependent uptake of glutamine by mouse blastocysts at $37^{\circ} \mathrm{C}$. Each point represents 5-10 embryos, mean \pm SEM from five experiments. (a) The line was fitted to the equation $v=K_{0}[\mathrm{Gln}]+V_{\max }[\mathrm{Gln}] / K_{\mathrm{m}}+[\mathrm{Gln}]$ with $K_{0} 40 \mathrm{pl}$ per embryo per $10 \mathrm{~min}, K_{\mathrm{m}}$ $524 \mu \mathrm{mol} \mathrm{l}^{-1}$ and $V_{\max } 1264 \mathrm{fmol}$ per embryo per $10 \mathrm{~min}$. (b) After allowance for diffusion (as above), the data were transformed to an Eadie-Hofstee plot and the line was fitted by linear regression, $n=11, r=0.61, P<0.05$.

\section{Discussion}

The chromatography established that at least $90 \%$ of the radiolabel taken up by blastocysts over $10 \mathrm{~min}$ remained as glutamine. In addition to confirming that embryo-derived ${ }^{3} \mathrm{H}$ represents accumulated glutamine, this result indicates that the conversion of glutamine to other metabolites is slow, as observed by Chatot et al. (1990).

Glutamine was readily taken up by two-cell embryos, confirming previous studies (Gardner $e t$ al., 1989; Chatot et al., 1990). However, the present results show that the rate of glutamine uptake at $0 \cdot 1$ and $1 \mathrm{mmol}^{-1}$ varies with time and was constant only over the initial $30 \mathrm{~min}$ in two-cell embryos. The initial rate varied with the concentration of glutamine, thus indicating that the kinetics of uptake are complex (Fig. 3).

In these studies, each embryo accumulated radioactivity. This contrasts with the 'negative uptake' or loss of embryonic glutamine by some embryos reported by Gardner et al. (1989). It is not possible to measure efflux of $\left[{ }^{3} \mathrm{H}\right]$ glutamine without preaccumulation. However, it is possible that the small efflux apparent after $15 \mathrm{~min}$ in our studies could become significant over $2 \mathrm{~h}$ and approach the rates of loss observed in that earlier study. Our aim was primarily to determine the extent of reversibility of the transport system, and the data suggest this to be a minor component of the net flux of glutamine across the embryonic membranes. 


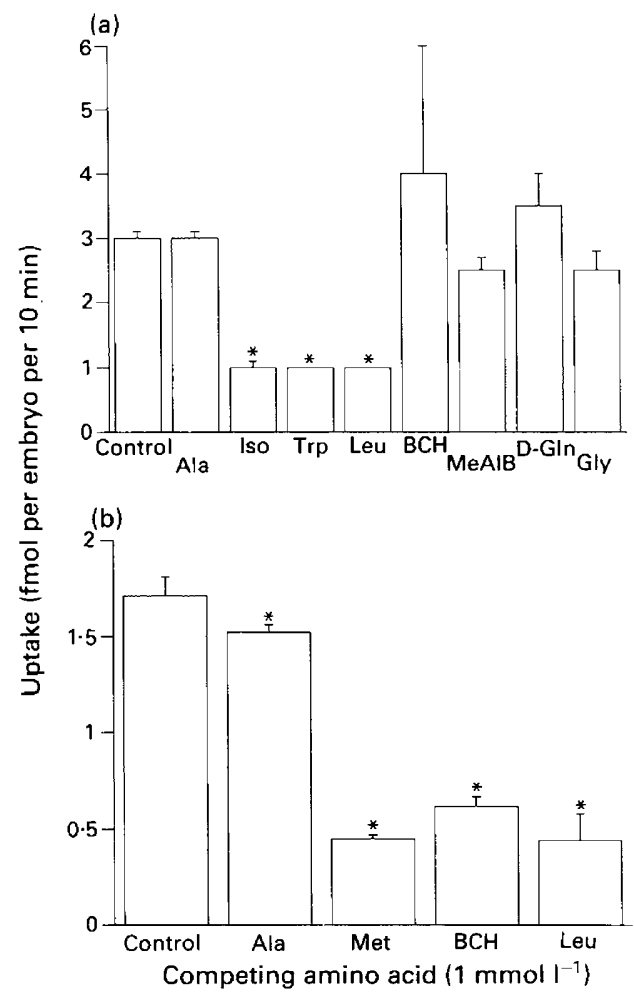

Fig. 5. Uptake of $\left[{ }^{3} \mathrm{H}\right]$ glutamine by two-cell mouse embryos (a) in the presence or (b) in the absence of $\mathrm{Na}^{+}$and in the presence of alanine (Ala), isoleucine (Iso), tryptophan (Trp), leucine (Leu), 2-amino-2-norbornanecarboxylic acid (BCH), methylaminoisobutyric acid, (MeAIB), D-glutamine (D-Gln), methionine (Met), or glycine (Gly); *significantly lower than control value $(P<0.05)$, mean \pm SEM from three experiments each with 6-8 embryos.

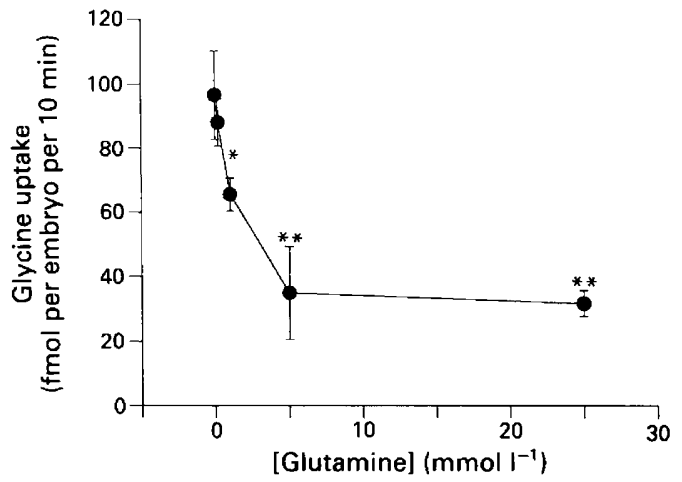

Fig. 6. Glutamine inhibition of $23 \mu \mathrm{mol} 1^{-1}\left[{ }^{3} \mathrm{H}\right]$ glycine uptake by two-cell mouse embryos. Significantly less than value with no glutamine, ${ }^{*} P<0.05,{ }^{* *} P<0.005$. Each point represents mean \pm SEM from two experiments with 4-8 embryos per trial. 


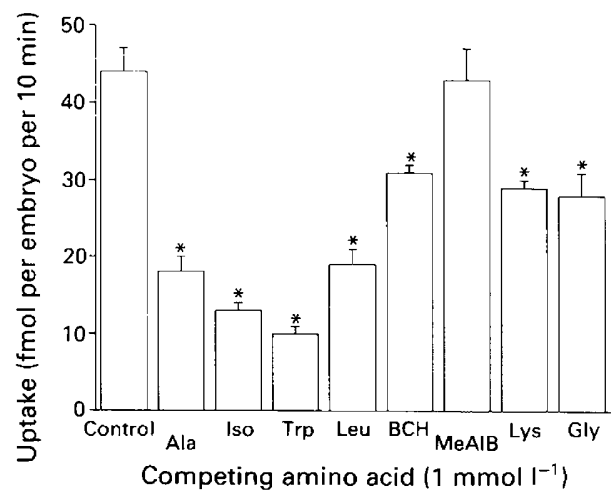

Fig. 7. Uptake of $\left[{ }^{3} \mathrm{H}\right]$ glutamine by mouse blastocysts in the presence of alanine (Ala), isoleucine (Iso), tryptophan (Trp), leucine (Leu), 2-amino-2-norbornanecarboxylic acid $(\mathrm{BCH})$, methylaminoisobutyric acid (MeAIB), lysine (Lys) or glycine (Gly). Each point comprises 5-8 embryos from two experiments, mean \pm SEM; *significantly less than control value $(P<0.05)$.

The total uptake of glutamine by two-cell embryos was resolved into two saturable components. The major component was $\mathrm{Na}^{+}$-independent and accounted for about $85 \%$ of the total glutamine uptake at $0.1 \mathrm{mmol} 1^{-1}$, to about $70 \%$ at $10 \mathrm{mmol}^{-1}$. This component is probably the transporter system $\mathrm{L}$, which is the principal transporter system of leucine in cleaving mouse embryos (Holmberg \& Johnson, 1979). This system is also responsible, but to a lesser degree, for the transport of tryptophan, isoleucine, methionine, alanine and BCH (Van Winkle, 1988), all of which effectively inhibited $\mathrm{Na}^{+}$-independent glutamine uptake in two-cell mouse embryos.

The significant inhibition of glycine uptake in two-cell embryos by glutamine at concentrations $>1 \mathrm{mmol}^{-1}$ (Fig. 6) indicates that there is a $\mathrm{Na}^{+}$-dependent component of glutamine uptake, accounting for approximately $35 \%$ of the total uptake in two-cell embryos. This is probably due to transport via system $g l y$, which is the exclusive glycine transporter in two-cell embryos (Hobbs \& Kaye, 1985, 1986; Van Winkle et al., 1988). The $V_{\max }$ value for glutamine $(107 \pm 47 \mathrm{fmol}$ per embryo per $10 \mathrm{~min}$ ) is within the range reported for glycine uptake (Hobbs \& Kaye, 1990).

In blastocysts, uptake of glutamine occurred at a constant rate of $33 \mathrm{fmol} \mathrm{embryo}{ }^{-1}$ per min for at least $60 \mathrm{~min}$ at $100 \mu \mathrm{mol}^{-1}$. This is comparable with the rate reported previously under similar conditions (Gardner et al., 1989; Chatot et al., 1990).

A small amount of glutamine entered blastocysts in the absence of $\mathrm{Na}^{+}$and may be due to simple diffusion (Hobbs \& Kaye, 1990), since there was no evidence for a second saturable system. Most glutamine uptake $(99 \%)$ was $\mathrm{Na}^{+}$-dependent and saturable. The $V_{\max }$ value is close to that reported for alanine and glycine by system $\mathrm{B}^{0,+}$ (Van Winkle et al., 1988). As glutamine uptake was inhibited by alanine, isoleucine, tryptophan, leucine, lysine, $\mathrm{BCH}$ and glycine, all known to be transported in blastocysts by system $\mathbf{B}^{0,+}$ (Hobbs \& Kaye, 1985; Van Winkle \& Campione, 1987) and not by MeAIB, a specific competitor for system $\mathrm{A}$, we conclude that this $\mathrm{Na}^{+}$-dependent system $\left(\mathrm{B}^{0,+}\right)$ is the major means of glutamine uptake in blastocysts.

Recently, alanine uptake in blastocysts has been resolved into two components, $\mathrm{B}^{+, 0}$ and $\mathrm{B}$, on the basis of differential inhibition by lysine and BCH (Van Winkle et al., 1990). The residual uptake of glutamine by blastocysts in the presence of these inhibitors may indicate a similarly small contribution of system B to glutamine uptake, but this was not investigated because of the number of embryos required.

In conclusion, our results show that glutamine, in common with most amino acids, enters mouse embryos predominantly by facilitated transport systems. During development there is a change in the major transporter systems responsible for glutamine uptake from systems $\mathrm{L}$ and $g l y$ in two-cell embryos to system $\mathrm{B}^{0,+}$ in blastocysts. This shift probably occurs at about the morula 
stage of development similar to that reported for the transport of other amino acids such as alanine (Van Winkle et al., 1990).

The threefold increase in $V_{\max }$ for glutamine uptake during development to the blastocyst stage may account for the threefold increase in the embryonic pool of glutamine (Shultz et al., 1981). This increased uptake capacity may enable blastocysts to provide for the large increase in protein synthesis that occurs after compaction (Brinster, 1971; Sellens et al., 1981; Harvey \& Kaye, 1988).

We thank K. Markham and S. Murdoch for technical assistance. This work was supported by a project grant from the National Health and Medical Research Council of Australia.

\section{References}

Bae, I.H. \& Foote, R.H. (1975) Carbohydrate and amino acid requirements and ammonia production of rabbit follicular oocytes matured in vitro. Experimental Cell Research 91, 113-118.

Brinster, R.L. (1971) Uptake and incorporation of amino acids by preimplantation mouse embryo. Journal of Reproduction and Fertility 27, 329-338.

Carney, E.W. \& Bavister, B.D. (1987) Stimulatory and inhibitory effects of amino acids on development of hamster eight-cell embryos in vitro. Journal of In Vitro Fertility and Embryo Transfer 4, 162-167.

Chatot, C.L., Tasca, R.J. \& Ziomek, C.A. (1990) Glutamine uptake and utilization by preimplantation mouse embryos in CZB medium. Journal of Reproduction and Fertility 89, 335-346.

Christensen, H.N. (1979) Organic ion transport during seven decades. The amino acids. Biochimica et Biophysica Acta 779, 225-269.

Duggleby, R. (1984) Regression analysis of non-linear Arrhenius plots: an empirical model and a computer program. Computers in Biology and Medicine $14,447-455$.

Fulton, B.P. \& Whittingham, D.G. (1978) Activation of mammalian oocytes by intracellular injection of calcium. Nature 273, 149-151.

Gardner, D.K. \& Leese, H.J. (1990) Concentrations of nutrients in mouse oviduct fluid and their effects on embryo development and metabolism in vitro. Journal of Reproduction and Fertility 88, 361-368.

Gardner, D.K., Clarke, R.N., Lechene, C.P. \& Biggers, J.D. (1989) Development of a noninvasive ultramicrofluorometric method for measuring net uptake of glutamine by single preimplantation mouse embryos. Gamete Research 24, 427-438.

Gwatkin, R.B.L. \& Haidri, A.A. (1973) Requirements for the maturation of hamster oocytes in vitro. Experimental Cell Research 76, 1-7.

Harvey, M.B. \& Kaye, P.L. (1988) Insulin stimulates protein synthesis in compacted mouse embryos. Endocrinology 122, 1182-1184.

Hobbs, J.G. \& Kaye, P.L. (1985) Glycine transport in mouse eggs and preimplantation embryos. Journal of Reproduction and Fertility 74, 77-86.

Hobbs, J.G. \& Kaye, P.L. (1986) Glycine and $\mathrm{Na}^{+}$transport in preimplantation mouse embryos. Journal of Reproduction and Fertility 77, 61-66.
Hobbs, J.G. \& Kaye, P.L. (1990) Glycine uptake in preimplantation mouse embryos: kinetics and effects of external $\left[\mathrm{Na}^{+}\right]$. Reproduction Fertility and Development 2, 651-660.

Holmberg, S.R.M. \& Johnson, M.H. (1979) Amino acid transport in unfertilized and fertilized mouse eggs. Journal of Reproduction and Fertility 56, 223-231.

Petters, R.M., Johnson, B.H., Reed, M.L. \& Archibong, A.E. (1990) Glucose, glutamine and inorganic phosphate in early development of the pig embryo in vitro. Journal of Reproduction and Fertility 89, 269-275.

Rieger, D. \& Guay, P. (1988) Measurement of the metabolism of energy substrates in individual bovine blastocysts. Journal of Reproduction and Fertility 83, 585-591.

Schultz, G.A., Kaye, P.L., McKay, D.J. \& Johnson, M.H. (1981) Endogenous amino acid pool sizes in mouse eggs and preimplantation embryos. Journal of Reproduction and Fertility 61, 387-393.

Sellens, M.H., Stein, S. \& Sherman, M.I. (1981) Protein and free amino acid content in preimplantation mouse embryos and in blastocysts under various culture conditions. Journal of Reproduction and Fertility 61, 307-315.

Van Winkle, L.J. (1988) Amino acid transport in developing animal oocytes and early conceptuses. Biochimica et Biophysica Acta 947, 173-208.

Van Winkle, L.J. \& Campione, A.L. (1987) Development of amino acid transport system $\mathrm{B}^{0,+}$ in mouse blastocysts. Biochimica et Biophysica Acta 925, 164-174.

Van Winkle, L.J., Haghighat, N., Campione, A.L. \& Gorman, J.M. (1988) Glycine transport in mouse eggs and preimplantation conceptuses. Biochimica et Biophysica Acta 941, 241-256.

Van Winkle, L.J., Campione, A.L. \& Farrington, B.H. (1990) Development of system $\mathrm{B}^{+.0}$ and a broadscope $\mathrm{Na}^{+}$-dependent transporter of zwitterionic amino acids in preimplantation mouse conceptuses. Biochimica et Biophysica Acta 1025, 225-233.

Zielke, H.R., Zielke, C.L. \& Ozand, P.T. (1984) Glutamine: a major energy source for cultured mammalian cells. Proceedings of the Federation of the American Society for Experimental Biology 43, 121-125.

Received 5 March 1991 